Original Research Paper

\title{
Pelatihan Rancang Bangun Sistem Monitoring Kondisi Air Tambak Berbasis Internet of Things (IoT) di SMK Perikanan dan Kelautan Kecamatan Puger Kabupaten Jember
}

\author{
Alfian Pramudita Putra ${ }^{1}$, Riries Rulaningtyas ${ }^{1}$, Franky Chandra Satria Arisgraha ${ }^{1}$

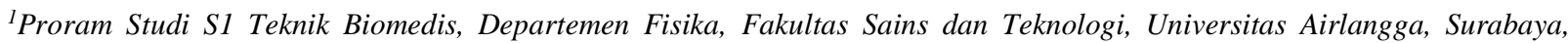 \\ Indonesia
}

https://doi.org/10.29303/jpmpi.v3i2.1007

Sitasi: Putra, A. P., Rulaningtyas, R., Satria. F. K \& Arisgraha, F. C. S. (2021). Pelatihan Rancang Bangun Sistem Monitoring Kondisi Air Tambak Berbasis Internet of Things (IoT) di SMK Perikanan dan Kelautan Kecamatan Puger Kabupaten Jember. Jurnal Pengabdian Magister Pendidikan IPA, 4(4)

\section{Article history}

Received: 20 September 2021

Revised: 30 September 2021

Accepted: 10 Oktober 2021

*Corresponding Author: Alfian Pramudita Putra, Teknik

Biomedis, Universitas

Airlangga, Surabaya, Indonesia. Email:

alfian.pramudita@fst.unair.ac.id

\begin{abstract}
Kualitas air tambak atau kolam budidaya ikan atau udang merupakan aspek external yang harus diperhatikan. Permasalahan utama dalam kegagalan produksi ikan atau udang adalah buruknya kualitas air selama masa pemeliharaan, terutama pada tambak intensif. Sebagian besar pekerjaan monitoring telah dibantu teknologi informasi untuk memudahkan dalam pelaksanaan pemantauan. Salah satunya adalah dengan penggunaan Internet of Things (IoT). Sistem IoT ini dapat digunakan para petambak untuk memantau kondisi perarian tambak sehingga produksi mereka bisa meningkat. Melalui kegiatan pengabdian masyarakat Program Kemitraan Masyarakat ini, sistem yang dapat memantau suhu dan $\mathrm{pH}$ dari perariran secara kontinu telah dibuat dengan memanfaatkan IoT. Hal ini bermanfaat untuk para siswa SMK sehinga mereka dapat meningkatkan kemampuan di bidang teknologi yang tetap berkaitan dengan perikanan dan kelautan. Peserta pelatihan sangat antusias terhadap pelaksanaan kegiatan karena mendapatkan pengetahuan baru terkait mikrokontroler dan IoT. Selain itu, Siswa SMK dapat memiliki tambahan kemampuan dan pengetahuan yang berguna untuk bersaing di dunia kerja, khususnya pada era revolusi industri 4.0.
\end{abstract}

Keywords: Internet of Things (IoT); Kemitraan untuk Mencapai Tujuan; Monitoring Kondisi Air; Teknologi

\section{Pendahuluan}

$\mathrm{P}$ erkembangan dunia kewirausahaan di bidang budidaya perairan telah berkembang sejak tahun 2015 oleh Dinas Perikanan Kabupaten Jember, terutama di kecamatan Puger yang berlokasi di dekat pantai selatan Jawa. Daerah tersebut telah mampu membudidayakan udang Vaname dengan potensi pasar hingga ke luar negeri, seperti Eropa, Amerika dan Asia (Ilham, 2016). Dalam pelaksanaannya, dibutuhkan modal yang tinggi. Banyak pihak yang terkait dalam proses wirausaha tersebut yang masih memerlukan peningkatan kualitasnya (Marti'ah, 2017). Salah satunya yang bisa dilakukan sebagai upaya dukungan akan hal tersebut adalah penggunaan teknologi tepat guna yang mampu memonitor kondisi wirausaha yang berkaitan dengan perairan ini.

Kualitas air tambak atau kolam budidaya ikan atau udang merupakan aspek external yang harus diperhatikan. Permasalahan utama dalam kegagalan produksi ikan atau udang adalah buruknya kualitas air selama masa pemeliharaan, terutama pada tambak intensif (Arsad dkk, 2017). 
Salah satu penyebab buruknya kualitas air tambak adalah karena adanya dinamika kualitas air tambak yang dapat berubah-ubah setiap saat. Hal ini disebabkan oleh pengunaan pakan yang banyak karena kepadatan tebar yang tinggi. Udang hanya dapat menyerap sekitar $16,3-40,87 \%$ protein pakan dan sisanya dibuang dalam bentuk feses atau ekstraksi residu pakan (Hari et al., 2004). Pakan yang tidak termakan, feses, dan organisme yang mati seperti plankton, bakteri, dan lain-lain menghasilkan limbah budidaya. Akumulasi limbah budidaya menyebabkan timbulnya kondisi anaerob di sedimen perairan. Kondisi anaerob pada limbah dapat menginduksi reaksi pembentukan $\mathrm{H} 2 \mathrm{~S}$ oleh bakteri sulfida dari asam amino yang mengandung ion sulfida (Umar dkk, 2001).

Perkembangan teknologi informasi di era industri 4.0 ini sangatlah maju. Sebagian besar pekerjaan monitoring telah dibantu teknologi informasi untuk memudahkan dalam pelaksanaan pemantauan. Salah satunya adalah dengan penggunaan Internet of Things (IoT). Sistem IoT ini dapat digunakan para petambak untuk memantau kondisi perarian tambak sehingga produksi mereka bisa meningkat (Rahayu dkk., 2017). Parameter yang perlu dipantau untuk kondisi perarairan tambak meliputi suhu dan $\mathrm{pH}$. Pemantauan tersebut dilakukan secara online sehingga informasi dan juga kondisi dari tambak dapat dipantau secara real time. Jika suatu saat diketahui adanya anomali, maka petambak bisa segera mengambil tindakan untuk mengatasi masalah yang ada.

Berdasarkan analisis situasi tersebut, maka melalui kegiatan pengabdian masyarakat Program Kemitraan Masyarakat ini akan dibuat sistem yang dapat memantau suhu dan $\mathrm{pH}$ dari perariran secara kuntinu dengan memanfaatkan IoT. Hal ini akan bermanfaat untuk para siswa SMK sehinga mereka dapat meningkatkan kemampuan di bidang teknologi yang tetap berkaitan dengan perikanan dan kelautan. Oleh karena itu melalui program kemitraan masyarakat ini juga akan diberikan bekal keahlian kepada siswa SMK Perikanan dan Kelautan Puger yang memiliki kekhususan dalam bidang perikanan. Sehingga selain dapat membantu petani tambak juga dapat melatih siswa SMK untuk secara mandiri mengembangkan produksi dan pengadaan alat yang bermanfaat bagi masyarakat di Indonesia dalam menghadapi Masyarakat Ekonomi Eropa (MEA) berdasarkan keahlian di bidang yang ditekuni setelah lulus nantinya (Ain, dkk., 2021).

\section{Metode}

Kegiatan pengabdian kepada masyarakat ini bermitra dengan SMK Perikanan dan Kelautan Puger dan juga CV. Inbiomed Tech. Para siswa SMK Perikanan dan Kelautan diberikan pelatihan dalam membuat sistem pemantauan kondisi air tambak dengan memanfaatkan teknologi Internet of Things (IoT). Pelatihan dilaksanakan secara daring dan siswa datang ke sekolah yang beralamat di Jl. A. Yani, Krajan II, Puger Kulon, Puger, Kabupaten Jember, Jawa Timur 68164.

Pelatihan pada siswa SMK diberikan oleh mahasiswa S1 Teknik Biomedis yang telah dilatih terlebih dahulu oleh mitra industri, yakni CV. Inbiomed Tech. yang merupakan start-up dari alumni S1 Teknik Biomedis yang bergerak di bidang prototyping alat kesehatan dan bidang lainnya. Pelatihan yang diberikan berupa pembuatan sistem IoT untuk memantau kondisi air meliputi suhu, $\mathrm{pH}$, dan kekeruhan. Alat yang dibutuhkan untuk pelaksanaan pelatihan meliputi, kit ESP32, sensor suhu, resistor, website Thingspeak dan beberapa komponen elektronik pendukung.

Program pengabdian kepada masyarakat ini dibagi menjadi 2 sesi, yaitu sesi pemaparan materi oleh dosen Departemen Fisika, Fakultas Sains dan Teknologi, Universitas Airlangga mengenai dasar mikrokontroler dan juga kegunaan Internet of Things dan kemudian dilanjut dengan sesi pelatihan yang dipandu oleh mahasiswa S1 Teknik Biomedis. Jumlah Siswa yang ikut dalam pelatihan ini adalah 20 siswa SMK yang berasal dari bidang minat Agribisnis Perikanan Payau dan Laut dan Teknik Konstruksi Kapal. Mereka dibagi menjadi 10 kelompok yang dipandu oleh 1 mahasiswa.

Pembuatan sistem monitoring perairan tambak berbasis IoT ini meliputi perancangan software pada ESP32 yang tujuannya untuk mengumpulkan nilai $\mathrm{pH}$, suhu, dan kekeruhan yang diperoleh dari sensor yang ditampilkan melalui display monitor yang ada melalui web Thinkspeak. Perubahan nilai $\mathrm{pH}$, suhu, dan kekeruhan dapat dipantau secara real time melalui web tersebut. Siswa SMK akan berlatih untuk merangkai sistem sederhana menggunakan sensor suhu untuk kemudian dihubungkan dengan internet dan hasilnya dipantau melalui web yang telah didesain secara mandiri, hingga akhirnya para siswa menjadi 
paham untuk mewujudkan suatu sistem monitoring perariran berbasis IoT.

Pemrograman akan dilakukan melalui Arduino IDE untuk memfungsikan seluruh sensor dalam alat sesuai kebutuhan. API yang telah di dapat dari Thingspeak juga turut dimasukkan ke dalam syntax (Pasha, 2016).

Thingspeak digunakan dalam penelitian ini dikarenakan aksesibilitasnya yang tinggi, dimana kita tidak perlu memiliki server pribadi dan juga tampilan akhir pengamatan yang akan tersaji dengan rapih di laman Thingspeak. Seusai program dimasukkan ke dalam ESP32 dan alat telah bekerja. Langkah selanjutnya adalah mengupload data dari alat menuju Thingspeak. Hal pertama yang akan dilakukan adalah memasuki situs (https://thingspeak.com/) kemudian melakukan sign up. Setelah terdaftar, cek Application Programming Interface (API) key untuk baca dan tulis pada cloud. API baca berfungsi untuk membaca data yang sudah dikirim ke cloud dan yang sudah di analisis di ThingSpeak, API baca memungkinkan orang lain melihat data dan grafik pada channel pribadi. Sedangkan, API tulis berfungsi untuk verifikasi pengiriman data sensor menuju cloud di channel tertentu. Langkah selanjutnya adalah menulis API tulis di Arduino IDE, setelah itu upload dan complile kode program menuju ESP32. Setelah proses compiling berhasil, cek API baca dan masuk ke web Thingspeak dan paramater-parameter sensor seharusnya sudah dikirim secara real time menuju cloud. Secara keseluruhan, blok diagram dan juga skema rangkaian sistem monitoring kondisi air tambak berbasis IoT dapat dilihat pada Gambar 1 dan 2 .

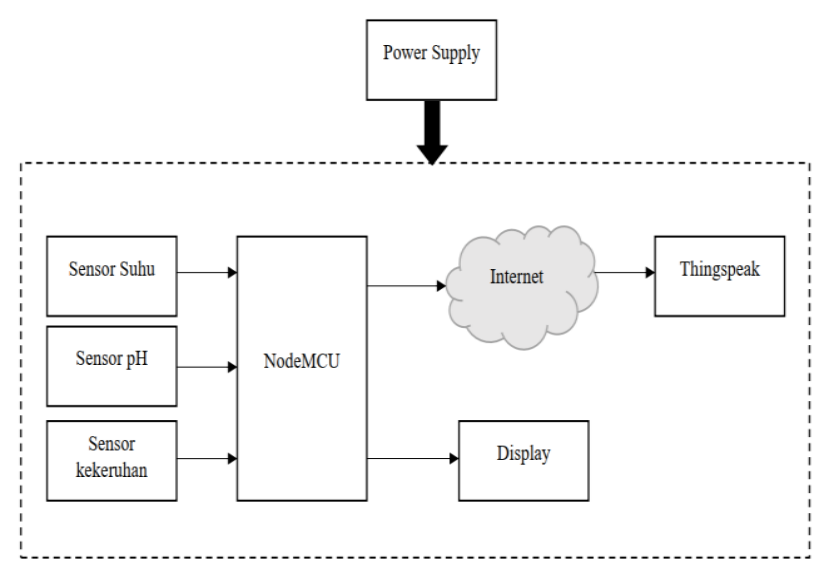

Gambar 1 Blok Diagram Sistem Monitoring Kondisi Air Tambak

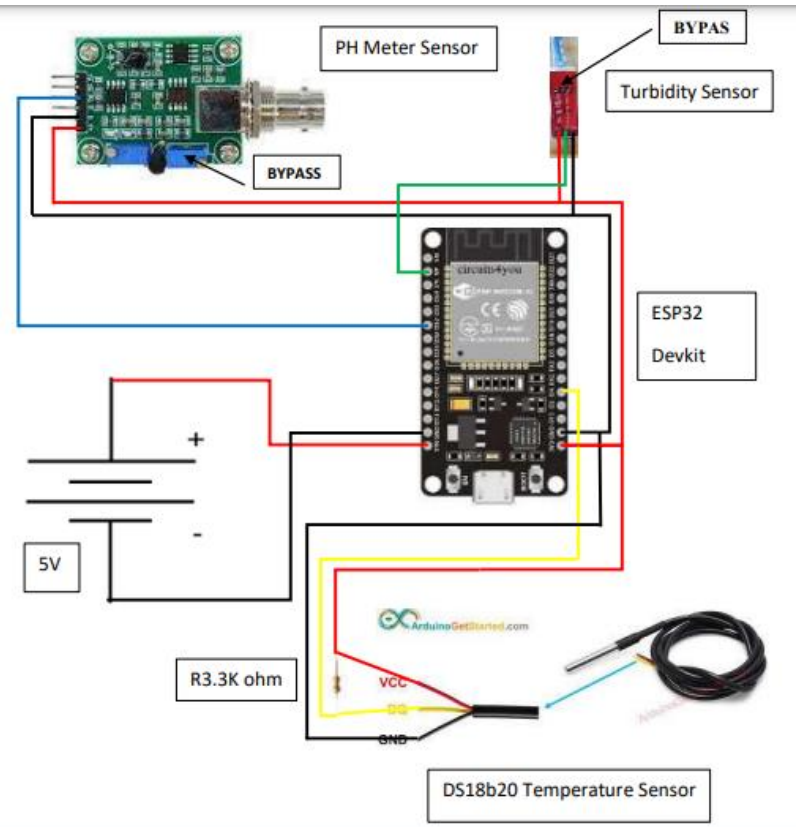

Gambar 2 Skema Rangkaian Sistem Monitoring Kondisi Air Tambak Berbasis IoT

Pelaksanaan kegiatan pengabdian kepada masyarakat ini dievaluasi dengan menggunakan pre-test dan post-test untuk siswa yang mengikuti pelatihan dan juga pemberikan kuisioner kepuasan pelaksanaan pelatihan yang diberikan. Pihak guru dan juga siswa juga diberikan kesempatan untuk menyampaikan pesan dan kesannya selama mengikuti pelatihan ini.

\section{Hasil dan Pembahasan}

Kegiatan pengabdian masyarakat yang bertemakan sistem monitoring kondisi air tambak ini dilakukan dalam 2 sesi, yaitu pemberian materi dasar dan pelatihan dasar mikrokontroler dan IoT kepada siswa-siswa SMK Perikanan dan Kelautan Puger. Kedua kegiatan ini dilakukan secara bersamaan pada tanggal 18 September 2021. Penyampaian materi dilakukan oleh Dr. Prihartini Widiyanti, drg., M.Kes., Akif Rahmatillah, S.T., M.T., dan Franky Chandra Satria Arisgraha, S.T., M.T. dengan tujuan memberikan pemahaman dasar mengenai pentingnya vaksinasi, dasar mikrokontroler dan IoT.

Pelaksanaan pelatihan dasar mikrokontroler dan IoT yang dilaksanakan Departemen Fisika dibuka oleh Kepala SMK Perikanan dan Kelautan Puger, Napak Drs. H. Kuntjoro Basuki, M.Si. beserta ketua pengabdian kepada masyarakat, yaitu Alfian Pramudita Putra, S.T., M.Sc.. Pemberian 
materi diawali dengan penyampaian tentang pentingnya vaksinasi COVID-19. Pemberian materi ini dilanjutkan dengan materi mikrokontroler dasar yang diberikan oleh Akif Rahmatillah, S.T., M.T. dan IoT oleh Franky Chandra S. A., S.T., M.T. yang membahas mengenai kegunaan mikrokontroler pada berbagai aspek, terutama di bidag perikanan dan kelautan dna juga menganai peran IoT dan bagainya pengguannya.

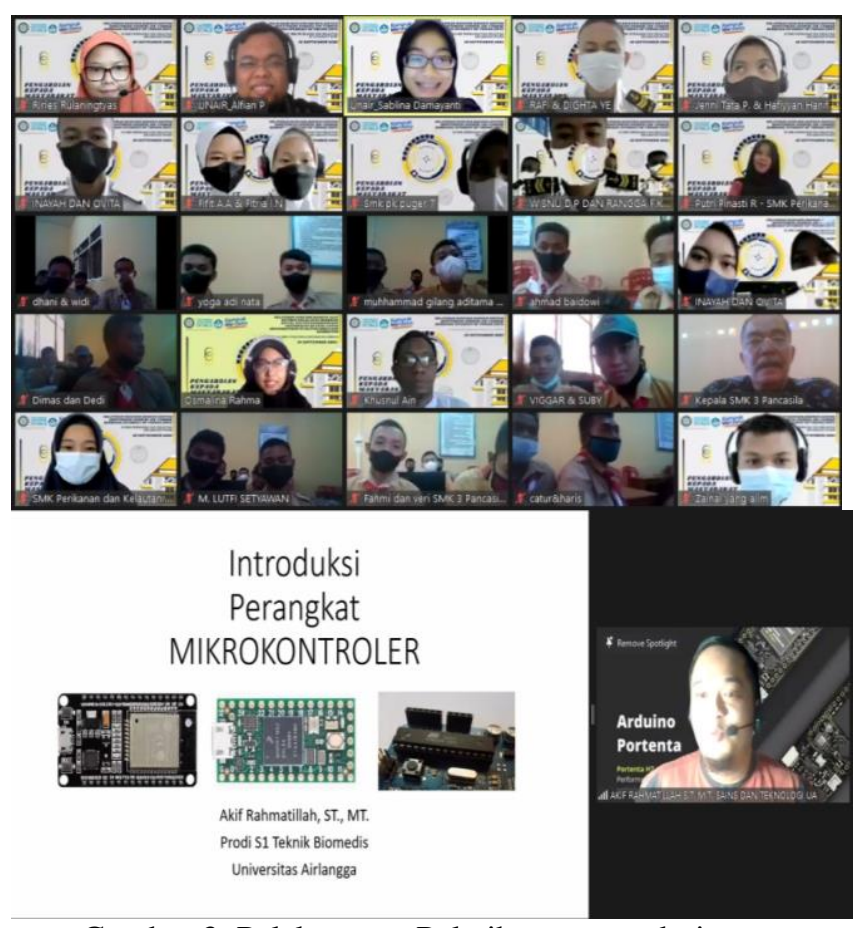

Gambar 3. Pelaksanaan Pelatihan secara daring

Pengenalan dasar mikrokontroler ini bertujuan agar para siswa mengetahui aplikasi elektronika yang lebih lanjut dan sudah banyak aplikasinya di kehidupan sehari-hari, salah satunya sebagai sistem deteksi kelelahan ini. Pelatihan meliputi pengertian mikrokontroler, jenis-jenisnya, bagian-bagiannya dan cara membuat program yang diisikan ke mikrokontroler tersebut. Pelatihan tidak hanya dengen sistem ceramah, tetapi juga melakukan praktik secara langsung dengan komponen-komponen mikronkontroler yang sudah ada. Pelaksanaan pelatihan dapat dilihat pada Gambar 3 dan 4.

Para siswa sangat antusias dengan adanya pelatihan mikrokontroler dan IoT ini, karena tidak hanya pemberian materi, tetapi juga melakukan praktik yang sangat berguna nantinya. Sebagian besar peserta juga ikut andil aktif dalam proses pelatihan, mulai dari memberikan berbagai macam pertanyaan, antusias dalam melakukan percobaan dan lain-lain. Mereka yang pada umumnya jarang mendapatkan praktikum yang berhubungan dengan elektronika menjadi bersemangat, apalagi ketika praktikum menggunakan mikrokontroler yang jarang pernah mereka temui.

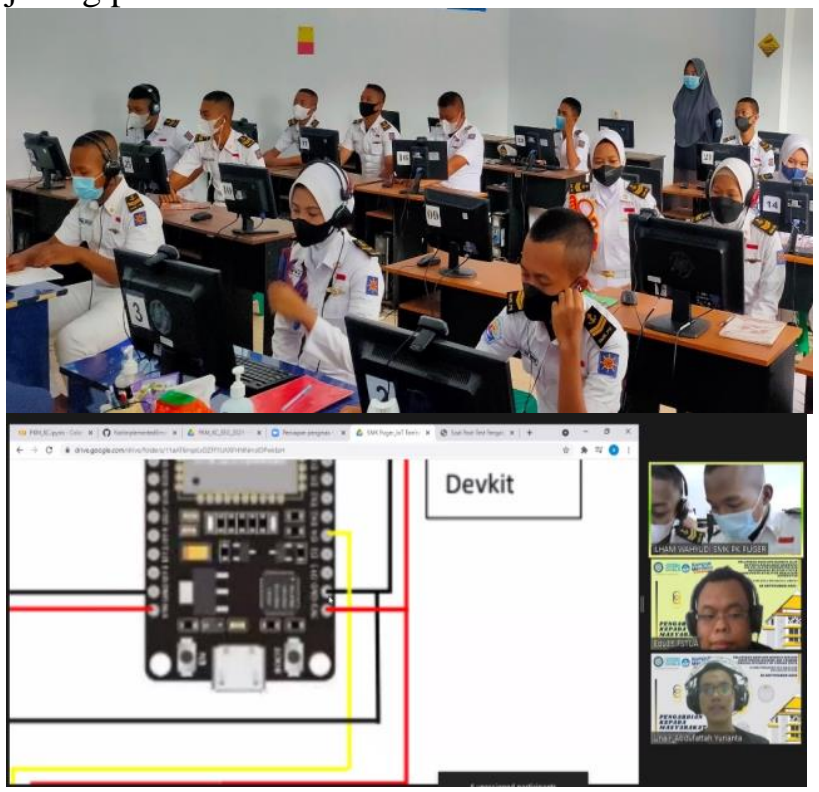

Gambar 4. Pelaksanaan Pelatihan secara Daring

Kegiatan pengabdian masyarakat ini juga melakukan evaluasi terhadap proses yang telah dilakukan dengan memberikan kuisioner kepada pasar peserta, dalam hal ini para siswa dan juga guru pendamping. Selain itu, juga ada pre-test dan post-test yang dikerjakan oleh para siswa terkait materi yang mereka dapatkan dalam pelatihan ini. Hasil dari kuisioner ini akan menjadi tolak ukur keberhasilan dari acara ini. Kuisioner ini berisi tentang kualitas materi dan narasumber, manajemen dan organisasi acara, fasilitas selama kegiatan pengabdian kepada masyarakat dan dukungan unit kerja terhadap pelaksanaan kegiatan. Sebagian besar peserta mengungkapkan bahwa acara pengabdian kepada masyarakat ini sangat bermanfaat dan diharapkan mampu berkelanjutan. Seperti yang telah disampaikan oleh Kepala SMK Perikanan dan Kelautan Puger, Bapak Drs. H. Kuntjoro Basuki, M.Si., "Saya mengucapkan banyak terima kasih atas kerjasama Tim Pengabdian Masyarakat Departemen Fisika dengan SMK Perikanan dan Kelautan. Semoga dapat banyak memberikan manfaat bagi kita semua dan siswa kami juga termotivasi untuk meningkatkan keahliannya. Semoga kegiatan seperti ini tetap bisa dilaksanakan ke depannya. Setidaknya ini adalah 
awal yang sangat baik. Tentu saja saya atas nama lembaga sangat berharap tindak lanjut dan kerjasama dalam bentuk lainnya. Hal-hal inovatif seperti inilah yang sangat diharapkan sekolah demi skill peserta didik yang lebih baik."

Hasil rekapitulasi nilai dari kuisioner yang telah diisi oleh peserta pelatihan dapat dilihat pada Tabel 1.

Tabel 1 Rekapitulasi Nilai Kuisioner Peserta Pelatihan

\begin{tabular}{|c|c|c|}
\hline No. & URAIAN & $\begin{array}{c}\text { SKOR } \\
(\%)\end{array}$ \\
\hline & I. Kualitas Materi dan Nara Sumber & \\
\hline 1 & Kemutakhiran Materi yang disajikan & 92.6 \\
\hline 2 & Kemanfaatan Materi yang diberikan & 93.8 \\
\hline 3 & Kualitas Penyampaian Materi & 94.2 \\
\hline \multirow[t]{2}{*}{4} & Kualitas Pendampingan Praktikum/Demo & 93.2 \\
\hline & II. Manajemen dan Organisasi & \\
\hline 5 & $\begin{array}{l}\text { Pemilihan Waktu (hari, tanggal, dan jam) } \\
\text { kegiatan yang tepat }\end{array}$ & 88 \\
\hline 6 & $\begin{array}{l}\text { Publikasi/Undangan Kegiatan Yang } \\
\text { Memadai }\end{array}$ & 88.6 \\
\hline 7 & $\begin{array}{l}\text { Pengaturan Waktu dan Acara Selama } \\
\text { Kegiatan }\end{array}$ & 88.8 \\
\hline 8 & $\begin{array}{l}\text { Kemudahan Memperoleh Informasi Dari } \\
\text { Panitia }\end{array}$ & 93.2 \\
\hline 9 & $\begin{array}{l}\text { Kualitas Layanan Panitia Selama } \\
\text { Kegiatan Pengmas }\end{array}$ & 88 \\
\hline & $\begin{array}{l}\text { III. Fasilitas Selama Kegiatan } \\
\text { Pengmas }\end{array}$ & \\
\hline 10 & $\begin{array}{l}\text { Ketersediaan Fasilitas Pendukung } \\
\text { Selama Kegiatan Berlangsung } \\
\text { Ketersediaan Fasilitas Media }\end{array}$ & 93.2 \\
\hline 11 & $\begin{array}{l}\text { Pembelajaran (LCD, Komputer, Peraga, } \\
\text { Peralatan Praktikum, dsb.) }\end{array}$ & 96.6 \\
\hline 12 & $\begin{array}{l}\text { Kenyamanan Ruang Kelas/Lab. Yang } \\
\text { Digunakan }\end{array}$ & 89.8 \\
\hline 13 & Ketersediaan Kit Pelatihan & 89.8 \\
\hline 14 & $\begin{array}{l}\text { Kualitas Konsumsi Yang Disediakan } \\
\text { IV. Dukungan Unit KerjaTerhadap } \\
\text { Pelaksanaan Kegiatan Pengmas }\end{array}$ & 96 \\
\hline 15 & $\begin{array}{l}\text { Sekolah tempat Saudara mengajar/belajar } \\
\text { mendukung kegiatan ini }\end{array}$ & 94.2 \\
\hline 16 & $\begin{array}{l}\text { Dinas Pendidikan di wilayah Saudara } \\
\text { mendukung kegiatan ini }\end{array}$ & 95.4 \\
\hline
\end{tabular}

Berdasarkan Tabel 1, terlihat bahwa sebagian besar peserta pelatihan menjawab dengan poin 4 atau lebih yang berarti sangat memuaskan ketika diberi pertanyaan mengenai kualitas materi dan narasumber, managemen dan organisasi acara, fasilitas selama kegiatan dan dukungan unit kerja terhadap pelaksanaan kegiatan pengabdian masyarakat. Hal ini menunjukkan bahwa material yang disampaikan mampu membuat para siswa tertarik, mudah dipahami, dan meningkatkan wawasan para peserta pelatihan. Selain itu, dari hasil tersebut merepresentasikan bahwa pembawa materi mampu menyampaikan materi dengan baik dan benar sesuai dengan target yang telah ditentukan di awal. Adanya praktik yang diberikan kepada para peserta mampu meningkatkan pemahaman peserta pelatihan terhadap materi yang telah diberikan. Suasana pelatihan yang kondusif didukung dengan aktifnya peserta dalam tanya jawab mampu menghidupkan suasana kelas. Hal ini ditunjukkan dengan nilai hasil kuisioner yang berkaitan dengan fasilitas selama kegiatan pengabdian kepada masyarakat dengan hasil memuaskan (nilai lebih dari 4).

Selain itu, pelaksanaan pengabdian kepada masyarakat kali ini yang kedua dilakukan secara daring dirasa cukup berhasil dimana peserta masih dapat berperan aktif selama kegiatan. Namun, memang pelatihan secara tatap muka langsung masih menjadi harapan semua peserta. Secara umum, hasil dari pelaksanaan kegiatan pengabdian kepada masyarakat ini berjalan dengan lancar, sangat memuaskan dan diharapkan dapat bersifat berkelanjutan.

Selain kuisioner yang berkaitan dengan kepuasan mitra dan juga peserta pengmas, hasil pre-test dan post-test para siswa juga menunjukkan peningkatan yang ditunjukkan pada Gambar 5.2 dan 5.3. Peningktaan yang didapat yaitu dari 59.24 ke 66.48 .

\section{Kesimpulan}

Kegiatan pengabdian masyarakat yang dilaksanakan di SMK Perikanan dan Kelautan Puger berjalan dengan baik dengan tema Pelatihan Rancang Bangun Sistem Monitoring Kondisi Air Tambak Berbasis Internet of Things (IoT) pada tanggal 18 September 2021. Pelaksanan kegiatan ini berjalan dengan hybrid, yaitu gabungan antara kegiatan daring dan luring. Pemberian materi dan pemanduan pelatihan dilakukan secara daring dan siswa SMK sebagai peserta pelatihan datang ke sekolah untuk melakukan pelatihan merangkai 
sistem monitoring secara langsung. Hasil dari kegiatan ini menunjukkan bahwa para siswa sangat antusias dalam mengikuti pelatihan dikarenakan mereka mendapatkan pengetahuan dan kemampuan baru terkait dengan teknologi IoT. Walaupun dalam keadaan pandemic seperti saat ini, proses pelaksanaan pelatihan tetap berjalan dengan baik. Semua pihak berharap kegiatan seperti ini dapat berlangsung secara kontinu dan bisa dikembangkan lagi di kegiatan mendatang.

\section{Saran}

Saran yang diberikan untuk kegiatan pelatihan serupa adalah pelaksanaannya yang dilakukan secara luring dan juga dengan waktu pelatihan yang lebih panjang sehingga lebih banyak praktek yang bisa dikerjakan.

\section{Ucapan Terima Kasih}

Penulis mengucapkan terima kasih kepada Fakultas Sains dan Teknologi Universitas Airlangga yang telah memberi dukungan finansial terhadap pelaksanaan kegiatan pengabdian masyarakat ini dengan Dana Rencana Kegiatan Anggaran Tahunan (RKAT) 2021 dengan Nomor 388/UN3/2021 Tanggal 7 Mei 2021.

\section{Daftar Pustaka}

Ain, K., Rulaningtyas, R., \& Putra, A. P. (2021). Pelatihan Rancang Bangun Alat Deteksi Kelelahan Berbasis Audiovisual untuk Meningkatkan Kualitas Kerja Dan Kesehatan di SMK 3 Pancasila Kecamatan Ambulu Kabupaten Jember Provinsi Jawa Timur. Jurnal Pengabdian Magister Pendidikan IPA, 4.

Arsad, S., dkk. 2017. Studi Kegiatan Budidaya Pembesaran Udang Vaname (Litopenaeus vannamei) dengan Penerapan Sistem Pemeliharaan Berbeda. Jurnal Ilmiah Perikanan dan Kelautan. 9 (1): 1-14.

Hari, B., B.M. Kurup., J.T. Varghese., J.W. Schrama and M.C.J. Verdegem. 2004. Effects of Carbohydrate Addition on Production in Extensive Shrimp Culture Systems. Aquaculture. 241: 179-194.

Ilham, DJ. 2016. Potensi Budidaya Perikanan Di
Jember Masih Terbuka Lebar. https://www.kissfmjember.com/2016/06/0 3/potensi-budidaya-perikanan-di-jembermasih-terbuka-lebar.html diakses pada tanggal 20 Maret 2021.

Marti'ah, S., 2017. Kewirausahaan Berbasis Teknologi (Technopreneurship) dalam Perspektif Ilmu Pendidikan. Jurnal Ilmiah Edutic. Vol. 3, No.2, hal. 75-82.

Pasha, S., 2016. Thingspeak Based Sensing and Monitoring System for IoT with Matlab Analysis. International Journal of New Technology and Research (IJNTR) Vol. 2, Issue 6, pp. 19-23

Rahayu, G., Sunarya, U., dan Novianti, A. 2017. Rancang Bangun Web Server Untuk Pemantauan Budidaya Udang Vannamei Menggunakan Teknologi IoT. Bandung : vol. 3, no. 3, pp. 2066-2071.

Umar, C., S.E. Kartamihardja., dan H. Supriyadi. 2001. Kemampuan bakteri Desulphovibrio $s p$. dalam penguraian senyawa belerang dan analisis laju sedimentasi, untuk perbaikan kualitas air pada budidaya keramba jaring apung. Jurnal Penelitian Perikanan Indonesia. 7 (2). 